\title{
ANALISIS EFEKTIVITAS POTENSI PENERIMAAN PAJAK HOTEL DAN RESTORAN, SERTA PAJAK AIR TANAH TERHADAP PENDAPATAN ASLI DAERAH KOTA TANGERANG DI DINAS PENGELOLAAN KEUANGAN DAERAH (DPKD) KOTA TANGERANG
}

\author{
Revi Yustiani ${ }^{1}$, Siti Maryama ${ }^{2}$ \\ ${ }^{1,2}$ Institut Teknologi dan Bisnis Ahmad Dahlan Jakarta \\ revirevitha.rr@gmail.com
}

\begin{abstract}
Local Original Revenue becomes very important because as a source of funding for the Regional Government which can be used as a benchmark in the implementation of regional autonomy and is one component of regional revenue sources, for example local income is the Hotel and Restaurant Tax, and Groundwater Tax. The purpose of this study was to determine the level of effectiveness of hotel and restaurant tax collection and groundwater tax in the city of Tangerang during 2015-2017 and to determine the contribution made by the hotel and restaurant tax and groundwater tax on the Local Original Revenue of the City of Tangerang during 2015- 2017. The data used in this study are secondary data with qualitative methods that refer to information collected from existing sources. Data analysis method used is descriptive analysis. Based on the results of the analysis, the level of effectiveness of hotel and restaurant taxes, as well as the Tangerang City groundwater tax during 2015-2017 was very effective and the contribution of hotel and restaurant tax revenue and groundwater tax on the Tangerang City's Local Original Revenues during 2015-2017 was very less.
\end{abstract}

Keywords : effectiveness, contributions, hotel tax, restaurant tax, groundwater tax, local original revenue. 


\section{PENDAHULUAN}

Pembangunan merupakan suatu proses yang berkesinambungan yang mencakup segala bidang dan ditujukan untuk meningkatkan kesejahteraan rakyat. Pemerintah Daerahlah yang berwenang untuk mengurus daerahnya masing-masing untuk mempercepat pembangunan tersebut. Dalam usaha mencapai tujuan pembangunan tersebut, pemerintah menciptakan tahap-tahap pelaksanaannya, baik untuk jangka panjang maupun jangka pendek yang meliputi perencanaan, pelaksanaan, pembiayaan, pengawasan dan evaluasi dengan tidak mengecilkan arti peran dari pihak-pihak lainya dalam berpartisipasi mensukseskan pembangunan nasional.

Seiring dengan diberlakukannya otonomi daerah maka dikenal pula istilh desentralisasi fiskal. Desentralisasi fiskal adalah pendelegasian kewenangan dan tanggung jawab fiskal dari Pemerintah Pusat kepada Pemerintah Daerah. Dengan diberlakukannya kebijakan desentralisasi fiskal, maka Pemerintah Daerah diberikan kewenangan untuk mengatur sistem pembiayaan dan pembangunan daerahnya sesuai dengan potensi dan kapasitasnya masing-masing.

Pendapatan Asli Daerah (PAD) merupakan penerimaan yang diperoleh dari sektor pajak daerah, retribusi daerah, hasil pengelolaan kekayaan daerah yang dipisahkan, dan lain-lain pendapatan asli daerah yang sah. Pendapatan Asli Daerah (PAD) menjadi sangat penting karena sebagai sumber pembiayaan Pemerintah Daerah dimana dapat dijadikan tolak ukur dalam pelaksanaan otonomi daerah dan merupakan salah satu komponen sumber pendapatan daerah, contoh pendapatan daerah adalah Pajak Hotel dan Restoran, Serta Pajak Air Tanah.

Pajak Hotel dan Restoran, Serta Pajak Air Tanah adalah salah satu potensi pendapatan daerah yang harus dikelola, karena Pajak Hotel dan Restoran, Serta Pajak Air Tanah sangat dibutuhkan didunia industri apapun, sehingga membuat kegiatan hotel, restoran dan pengambilan air tanah dimana-mana, maka hal tersebut harus ditertibkan dan diperhatikan perpajakannya karena merupakan salah satu penyumbang pendapatan daerah yang cukup menjanjikan bagi Pemerintah Daerah. Salah satu penerimaan daerah adalah Pajak Hotel, Pajak Restoran dan Pajak Air Tanah yang merupakan bagian dari Pajak Daerah. Pajak tersebut dikenakan terhadap pengusaha hotel, restoran dan pengambilan air tanah.

Pajak Hotel dan Restoran dikenakan dengan alasan bahwa mereka adalah pengusaha objek pajak dan pengambilan air tanah dipergunakan untuk operasional perusahaan, yang dilakukan oleh pemerintah. Pajak Hotel dan Restoran, serta Pajak Air Tanah adalah Pajak Daerah yang merupakan pajak yang dipungut oleh Pemerintah Daerah yang diatur berdasarkan peraturan daerah masing- masing dan hasil pungutannya digunakan untuk pembiayaan rumah tangga daerah.

Penelitian ini mengukur seberapa besar pengaruh variabel independent yaitu produk domestik regional bruto, industri dan penduduk terhadap variabel dependen yaitu Pajak Hotel dan Restoran, serta Pajak Air Tanah. Produk Domestik Regional Bruto adalh jumlah nilai tambah barang dan jasa yang dihasilkan dari seluruh kegiatan perekonomian diseluruh daerah dalam tahun tertentu atau periode tertentu dan biasanya satu tahun.

\section{KAJIAN PUSTAKA PENGEMBANGAN HIPOTESIS}

DAN

Pendapatan Asli Daerah adalah penerimaan yang diperoleh daerah dari sumber-sumber dalam wilayahnya sendiri yang dipungut berdasarkan peraturanperaturan daerah sesuai dengan peraturan perundang-undangan yang berlaku.

Besarnya penerimaan daerah dari sektor PAD akan sangat membantu pemerintah dalam melaksanakan kegiatan pembangunan di daerah serta dapat mengurangi ketergantungan pemerintah daerah terhadap pemerintah pusat sesuai dengan harapan yang diinginkan dalam otonomi daerah. Sumber-sumber 
Pendapatan Asli Daerah terdiri dari Pajak

Daerah, Retribusi Daerah, Hasil

pengelolaan kekayaan daerah yang

dipisahkan,dan Lain-lain PAD yang sah

\section{Pajak Daerah}

Pajak Daerah yaitu iuran wajib yang dipungut oleh pemerintah dari rakyatnya yang telah diatur oleh undang-undang, sehingga mempunyai landasan hukum yang kuat, tidak boleh bertentangan dengan pajak pemerintah pusat, dan Pajak Daerah ditujukan kepada masyarakat daerah tersebut semata-mata untuk pembangunan serta kesejahteraan masyarakat daerah itu sendiri. Jenis - jenis pajak daerah diantaranya Pajak Provinsi, terdiri atas Pajak Kendaraan Bermotor, Bea Balik Nama Kendaraan Bermotor, Pajak Bahan Bakar

Kendaraan Bermotor, Pajak Air Permukaan dan Pajak Rokok. Lalu, Pajak Kabupaten/Kota, terdiri atas Pajak Hotel, Pajak Restoran, Pajak Hiburan, Pajak Reklame, Pajak Penerangan Jalan, Pajak Mineral Bukan Logam dan Batuan, Pajak Parkir, Pajak Air Tanah, Pajak Sarang Burung Walet, Pajak Bumi dan Bangunan Perdesaan dan Perkotaan dan Bea Perolehan Hak atas Tanah dan Bangunan.

\section{Pajak Hotel}

Berdasarkan Peraturan Daerah Kota Tangerang Nomor 11 Tahun 2011 tentang Pajak Hotel. Pajak Hotel adalah pajak yang dipungut atas pelayanan yang disediakan oleh hotel dengan pembayaran, termasuk jasa penunjang sebagai kelengkapan hotel yang sifatnya memberikan kemudahan dan kenyamanan. Objek Pajaknya adalah pelayanan yang disediakan oleh hotel dengan pembayaran. Subjek pajaknya adalah orang pribadi atau badan yang melakukan pembayaran kepada yang mengusahakan hotel. Sedangkan wajib pajak hotel adalah orang pribadi atau badan yang membuka usaha hotel.

Dasar pengenaan pajak hotel adalah jumlah pembayaran yang diterima atau yang seharusnya diterima oleh pihak hotel. Yang termasuk jumlah pembayaran kepada hotel yaitu jumlah pembayaran setelah potongan harga dan jumlah pembayaran atas pembelian voucher menginap. Tarif Pajak Restoran ditetapkan sebesar $10 \%$ (sepuluh persen) dari pembayaran.

\section{Pajak Restoran}

Menurut Peraturan Daerah Kota Tangerang Nomor 11 Tahun 2011 tentang Pajak Restoran. Restoran adalah penyedia makanan atau minuman dengan dipungut bayaran, seperti rumah makan, kafetaria, kantin, warung, bar, dan sejenisnya termasuk jasa boga/catering. Pajak Restoran dipungut atas pelayanan yang disediakan oleh pihak restoran. Subjek pajak restoran adalah orang pribadi atau badan yang membeli makanan atau minuman dari restoran tersebut. Sedangkan wajib pajak adalah orang pribadi atau badan yang membuka usaha restoran.

Dasar pengenaan pajak restoran adalah jumlah pembayaran yang diterima oleh pihak restoran. Tarif Pajak Restoran ditetapkan sebesar $10 \%$ (sepuluh persen) dari pembayaran.

\section{Pajak Air Tanah}

Menurut Peraturan Daerah Kota Tangerang Nomor 11 Tahun 2011 tentang Pajak Air Tanah. Pajak air tanah adalah pajak atas pengambilan dan pemanfaatan air tanah. Objek Pajak air tanah yaitu Pengambilan dan pemanfaatan air tanah. Subjek pajak dan wajib pajak air tanah adalah orang pribadi atau badan yang melakukan pengambilan dan/atau pemanfaatan air tanah.

Dasar Pengenaan Pajak meliputi Nilai Perolehan Air Tanah, Nilai perolehan air tanah dinyatakan dalam rupiah yang dihitung dengan mempertimbangkan faktor-faktor berikut : Jenis sumber air; Lokasi sumber air; Tujuan pengambilan dan/atau pemanfaatan air; Volume air yang diambil dan/atau dimanfaatkan; Kualitas air dan tingkat kerusakan lingkungan dan meliputi, Penggunaan faktor-faktor sebagaimana dimaksud di atas disesuaikan dengan kondisi masing-masing daerah. Sedangkan besarnya Nilai Perolehan Air Tanah ditetapkan dengan Peraturan Bupati/Walikota. Tarif Pajak Air Tanah ditetapkan sebesar 20\% (dua puluh persen). 


\section{Efektivitas}

Efektivitas

kemampuan pemerintah daerah dalam merealisasikan pendapatan asli daerah apakah sudah sesuai dengan jumlah penerimaan pajak daerah yang ditargetkan. (Yoduke,2015). Rumus untuk mengukur efektivitas adalah sebagai berikut :

1. Efektivitas Pajak Hotel

$=\underline{\text { Realisasi Pajak Hotel }} \times 100 \%$

Target Pajak Hotel

2. Efektivitas Pajak Restoran

$=\underline{\text { Realisasi Pajak Restoran }} \times 100 \%$

Target Pajak Restoran

3. Efektivitas Pajak Air Tanah

$=$ Realisasi Pajak Air Tanah x

100\% Target Pajak Air Tanah

Indikator untuk mengetahui seberapa tingkat Efektivitas Pajak Daerah :

$\begin{array}{ll}>100 \% & =\text { Sangat efektif } \\ 90 \%-100 \% & =\text { Efektif } \\ 80 \%-90 \% & =\text { Cukup efektif } \\ 60 \%-80 \% & =\text { Kurang efektif } \\ <60 \% & =\text { Tidak efektif }\end{array}$

(Sumber: Yoduke, 2015)

\section{Kontribusi}

Kontribusi merupakan sumbangan berupa sumbangan uang, tenaga, pemikiran, materi, waktu, dan segala macam bentuk sumbangan yang diberikan untuk membantu suksesnya kegiatan yang telah direncanakan untuk mencapai tujuan bersama.

Untuk mengetahui kontribusi Pajak Hotel dan Restoran, serta Pajak Air Tanah terhadap PAD, dapat dihitung dengan menggunakan rumus sebagai berikut :

1. Kontribusi Pajak Hotel $=$ Realisasi Pajak Hotel x 100\%

Realisasi Penerimaan PAD

2. Kontribusi Pajak Restoran $=$ _Realisasi Pajak Restoran $100 \%$ Realisasi Penerimaan PAD

3. Kontribusi Pajak Air Tanah $=$ _Realisasi Pajak Air Tanah x 100\% Realisasi Penerimaan PAD
Tabel 1 Klasifikasi Kriteria Kontribusi

\begin{tabular}{|c|c|}
\hline Persentase & Kriteria \\
\hline$>50 \%$ & Sangat Baik \\
\hline $40 \%-50 \%$ & Baik \\
\hline $30 \%-40 \%$ & Cukup Baik \\
\hline $20 \%-30 \%$ & Sedang \\
\hline $10 \%-20 \%$ & Kurang Baik \\
\hline$<10$ & Sangat Kurang \\
\hline
\end{tabular}

Sumber : Tim Litbang Depdagri Fisiopol UGM (Putu Intan : 2015)

\section{METODE PENELITIAN}

\section{Populasi dan Sampel}

Data yang digunakan pada penelitian ini adalah data sekunder dengan metode kualitatif yang mengacu pada informasi yang dikumpulkan dari sumber yang telah ada. Data ini berupa data target dan realisasi Pajak Daerah di Kota Tangerang serta data potensi pendapatan Pajak Daerah di Kota Tangerang. Objek penelitian dalam penelitian ini adalah penerimaan pajak hotel dan restoran, serta pajak air tanah, sedangkan subjek penelitian ini dilakukan di Kota Tangerang dimana terdiri dari 29 Kecamatan dan 21 Sektor Industri. Waktu penelitian selama 4 bulan yaitu bulan Oktober 2019 Januari 2020. Sumber data yang digunakan dalam penelitian ini berupa data sekunder, yaitu data yang dikumpulkan dari Dinas Pengelolaan Keuangan Daerah (DPKD) dan Badan Pusat Statistik (BPS) yang berada di Kota Tangerang berupa Data Tarif Pajak Air Tanah, laporan tentang Pajak Hotel dan Restoran, serta Pajak Air Tanah dan PAD di Kota Tangerang selama periode 2015-2017.

\section{Metode Analisis Data}

Metode analisis yang akan dilakukan oleh peneliti dalam menganalisa data yang didapat dilakukan dengan cara : Pertama, Membuat tabel penerimaan Pajak Hotel dan Restoran, serta Pajak Air Tanah yang datanya diperoleh dari DPKD Kota Tangerang. Kedua, Menghitung efektifitas per tahun dengan membandingkan antara penerimaan dan realisasi Pajak Hotel dan Restoran, serta Pajak Air Tanah. Untuk menilai efektif atau tidaknya penerimaan Hotel, Restoran dan Air 
Tanah, maka dapat dilihat pada tabel interpretasi nilai efektifitas. Ketiga, Menghitung kontribusi Pajak Hotel dan Restoran, serta Pajak Air Tanah terhadap PAD Kota Tangerang. Untuk mengetahui seberapa besar kontribusi terhadap PAD dengan membandingkan realisasi penerimaan Hotel, Restoran dan Air Tanah dengan realisasi pendapatan dari tahun ke tahun selama tahun 2015-2017. Keempat, Membandingkan hasil perhitungan efektifitas dengan interpretasi nilai efektifitas, sehingga diketahui efektif atau tidaknya penerimaan Pajak Hotel dan Restoran, serta Pajak Air Tanah. Kelima, Membandingkan hasil perhitungan kontribusi dengan klasifikasi kriteria kontribusi yang diterima PAD dari Pajak Hotel dan Restoran, serta Pajak Air Tanah, kriteria tersebut bisa baik atau tidak baik. Keenam, Menganalisis hasil perhitungan efektifitas penerimaan Pajak Hotel dan Restoran, serta Pajak Air Tanah di Kota Tangerang berdasarkan tabel interpretasi nilai efektifitas. Apabila perhitungan efektifitas mendekati atau melebihi 100\% maka penerimaan Pajak Hotel dan Restoran, serta Pajak Air Tanah sangat efektif. Ketujuh, Menganalisis hasil perhitungan kontribusi Pajak Hotel dan Restoran, serta Pajak Air Tanah terhadap PAD berdasarkan klasifikasi kriteria kontribusi hasil analisis yang didapatkan akan nampak kontribusi terbesar dan terkecil dari tahun ke tahun. apabila kontribusi yang diterima mendekati atau melebihi 50\% maka kontribusi Pajak Hotel dan Restoran, serta Pajak Air Tanah semakin baik.

\section{HASIL DAN PEMBAHASAN}

Pemungutan Pajak Daerah di Kota Tangerang telah sesuai dengan UndangUndang Nomor 28 Tahun 2009. Setiap daerah memiliki peraturan daerah masingmasing, untuk daerah Kota Tangerang diatur dalam Peraturan Daerah Nomor 8 Tahun 2014 tentang Perubahan Atas Peraturan Daerah Nomor 7 Tahun 2010 Tentang Pajak Daerah.

Langkah pertama dalam pelaksanaan pemungutan pajak hotel dan restoran adalah Wajib pajak harus mendaftarkan diri terlebih dahulu ke Dinas Pengelolaan Keuangan Daerah di Kota Tangerang untuk mendapatkan NPWPD. Jika wajib pajak tidak mendaftarkan diri, kepala DPKD secara jabatan akan menerbitkan NPWPD berdasarkan data yang diperoleh atau dimiliki oleh DPKD.

Sedangkan untuk pendaftaran Wajib Pajak Air Tanah diatur dalam Peraturan Bupati Tangerang Nomor 7 Tahun 2011 tentang Pedoman Teknis Pelaksanaan Pemungutan Pajak Air Tanah, yaitu setiap Wajib Pajak Air Tanah wajib mendaftarkan usahanya ke DPKD dalam jangka waktu paling lama 30 (Tiga puluh) hari sebelum dimulainya kegiatan usahanya kecuali ditentukan lain. Apabila wajib pajak tidak melaporkan sendiri usahanya, maka DPKD akan mendaftarkan usaha wajib pajak secara jabatan.

\section{ANALISIS DAN INTERPRETASI HASIL \\ Analisis Efektivitas Pajak Hotel dan Restoran, serta Pajak Air Tanah}

Perhitungan efektivitas pemungutan pajak hotel dan restoran, serta pajak air tanah di Kota Tangerang Periode 2015- 2017 dapat dilihat pada Tabel berikut ini : 
Tabel 2 Efektivitas Pemungutan Pajak Hotel

\begin{tabular}{|c|c|c|c|c|}
\hline Tahun & $\begin{array}{c}\text { Target } \\
\text { (Rp) }\end{array}$ & $\begin{array}{c}\text { Realisasi } \\
\text { (Rp) }\end{array}$ & $\begin{array}{c}\text { Efektivitas } \\
(\%)\end{array}$ & Kriteria \\
\hline 2015 & $34,000,000,000$ & $43,724,486,803$ & 128.60 & Sangat Efektif \\
\hline 2016 & $45,000,000,000$ & $50,966,723,212$ & 113.26 & Sangat Efektif \\
\hline 2017 & $47,000,000,000$ & $51,812,742,453$ & 110.24 & Sangat Efektif \\
\hline \multicolumn{3}{|c|}{ Rata-Rata } & 117.37 & Sangat Efektif \\
\hline
\end{tabular}

Berdasarkan Tabel 2 memperlihatkan rata-rata efektivitas pajak hotel Kota Tangerang pada tahun 2015-2017 adalah sebesar $117,37 \%$ dengan kriteria Sangat Efektif karena menunjukkan nilai diatas $100 \%$.

Dari tabel di atas diketahui bahwa realisasi penerimaan dan target pajak hotel di Kota Tangerang pada tahun 2015-2017 selalu mengalami peningkatan setiap tahunnya. Tetapi jika dilihat kembali pada kolom efektivitas pada tahun 2016 dan 2017 mengalami penurunan. Pada tahun 2015 terlihat tingkat efektivitas sebesar $128,60 \%$, sedangkan ditahun 2016 mengalami penurunan sebesar $15,34 \%$ dan menjadi 113,26\%. Dan di tahun 2017 mengalami penurunan kembali sebesar $3,02 \%$ dan menjadi $110,24 \%$.

Efektivitas pajak hotel selalu mengalami penurunan kemungkinan karena ada permainan dari wajib pajak hotel yaitu memanipulasi penerimaan hotel sehingga untuk pengeluaran pajak hotelnya kecil, karena jika dilihat di data jumlah wajib pajak serta target dan realisasi penerimaan pajak hotel selalu mengalami peningkatan setiap tahunnya.

Meskipun efektivitas pajak hotel tidak selalu menunjukkan peningkatan setiap tahunnya, tetapi tingkat efektivitas pajak hotel Kota Tangerang masih dalam kriteria sangat efektif karena nilainya masih diatas $100 \%$.

Tabel 3 Efektivitas Pemungutan Pajak Restoran

\begin{tabular}{|c|c|c|c|c|}
\hline Tahun & $\begin{array}{c}\text { Target } \\
(\mathbf{R p})\end{array}$ & $\begin{array}{c}\text { Realisasi } \\
\text { (Rp) }\end{array}$ & $\begin{array}{c}\text { Efektivitas } \\
(\%)\end{array}$ & Kriteria \\
\hline 2015 & $190,000,000,000$ & $211,725,468,574$ & 111.43 & Sangat Efektif \\
\hline 2016 & $225,000,000,000$ & $230,409,614,187$ & 102.40 & Sangat Efektif \\
\hline 2017 & $234,000,000,000$ & $247,765,055,842$ & 105.88 & Sangat Efektif \\
\hline \multicolumn{3}{|c|}{ Rata-Rata } & 106.57 & Sangat Efektif \\
\hline
\end{tabular}

Sama halnya dengan Tabel 2, pada Tabel 3 ini diketahui bahwa realisasi penerimaan dan target pajak restoran di
Kota Tangerang pada tahun 2015-2017 selalu mengalami peningkatan setiap tahunnya. Namun untuk tingkat 
efektivitasnya di tahun 2016 menurun dan pada tahun 2017 meningkat kembali. Kemungkinan dikarenakan jumlah wajib pajak pada tahun 2016 menurun dari 915 wajib pajak restoran menjadi 494 wajib pajak restoran dan pada tahun 2017 meningkat kembali karena jumlah wajib pajak kembali meningkat sebanyak 145 wajib pajak restoran dan ditahun 2017 jumlah wajib pajak restoran menjadi 639.

Pada tahun 2015 tingkat efektivitas sebesar $111,43 \%$ dengan kriteria sangat efektif, sedangkan ditahun 2016 mengalami penurunan sebesar $9,03 \%$ dan menjadi $102,40 \%$ dengan kriteria sangat efektif. Di tahun 2017 mengalami kenaikan kembali sebesar 3,48\% dan menjadi 105,88\% dengan kriteria sangat efektif. Dan untuk rata-rata efektivitas pajak restoran di Kota Tangerang tahun 2015-2017 adalah sebesar 106,57\% dengan kriteria sangat efefktif.

Tabel 4 Efektivitas Pemungutan Pajak Air Tanah

\begin{tabular}{|c|c|c|c|c|}
\hline Tahun & $\begin{array}{c}\text { Target } \\
\text { (Rp) }\end{array}$ & $\begin{array}{c}\text { Realisasi } \\
\text { (Rp) }\end{array}$ & $\begin{array}{c}\text { Efektivitas } \\
(\%)\end{array}$ & Kriteria \\
\hline 2015 & $5,500,000,000$ & $5,941,131,044$ & 108.02 & Sangat Efektif \\
\hline 2016 & $5,500,000,000$ & $5,643,689,377$ & 102.61 & Sangat Efektif \\
\hline 2017 & $5,000,000,000$ & $5,569,725,821$ & 111.39 & Sangat Efektif \\
\hline \multicolumn{3}{|c|}{ Rata-Rata } & 107.34 & Sangat Efektif \\
\hline
\end{tabular}

Berbeda dengan tabel-tabel diatas, Tabel 4 ini memperlihatkan target pajak air tanah di Kota Tangerang selama dua tahun yaitu tahun 2015 dan 2016 memiliki target yang sama yaitu sebesar Rp. 5.500.000.000.000,-, sedangkan di tahun 2017 target pajak air tanah menurun menjadi Rp. 5.000.0000.000,-. Dan untuk realisasi pajak air tanah di Kota Tangerang untuk tahun 2015-2017 selalu mengalami penurunan setiap tahunnya.

Pada tahun 2015 tingkat efektivitas pajak air tanah di Kota Tangerang sebesar 108,02\%, sedangkan di tahun 2016 tingkat efektivitas mengalami penurunan sebesar $5,41 \%$ dan menjadi $102,61 \%$. Kemungkinan penurunan ini terjadi karena jumlah wajib pajak air tanah menurun dari 769 menjadi 725 wajib pajak air tanah.

Dan di tahun 2017 tingkat efektivitas mengalami kenaikan dan melebihi tingkat efektivitas di tahun 2015 yaitu naik sebesar $8,78 \%$ dan menjadi $111,39 \%$. Hal ini kemungkinan dikarenakan dua hal, yang pertama yaitu adanya peningkatan wajib pajak kembali sebanyak 7 wajib pajak dan menjadi 732 wajib pajak air tanah di tahun 2017. Dan yang kedua yaitu jumlah realisasi pajak air tanah di tahun 2017 mengalami peningkatan lebih besar dari pada tahun 2015 yaitu sebesar Rp. 569,725,821,-, sedangkan di tahun 2015 hanya sebesar Rp. 441.131.044,-. Dan untuk rata-rata pajak air tanah Kota Tangerang tahun 2015-2017 adalah sebesar $107.34 \%$ dengan kriteria sangat efektif.

Meskipun tidak selalu menunjukkan peningkatan setiap tahunnya, tetapi tingkat efektivitas pajak air tanah Kota Tangerang masih dalam kriteria sangat efektif karena nilainya masih diatas $100 \%$. 
Analisis Kontribusi Pajak Hotel dan Restoran, serta Pajak Air Tanah pada PAD Kota Tangerang
Perhitungan kontribusi pajak hotel dan restoran, serta pajak air tanah terhadap PAD Kota Tangerang Periode 2015-2017 dapat dilihat pada Tabel di bawah ini :

Tabel 5 Kontribusi Pajak Hotel

\begin{tabular}{|c|c|c|c|c|}
\hline Tahun & $\begin{array}{c}\text { Realisasi Pajak } \\
\text { Hotel (Rp) }\end{array}$ & $\begin{array}{l}\text { Realisasi PAD } \\
\text { (Rp) }\end{array}$ & $\begin{array}{c}\text { Kontribusi } \\
(\%)\end{array}$ & Kriteria \\
\hline 2015 & $43,724,486,803$ & $1,471,944,383,908$ & 2.97 & Sangat Kurang \\
\hline 2016 & $50,966,723,212$ & $1,590,080,330,000$ & 3.21 & Sangat Kurang \\
\hline 2017 & $51,812,742,453$ & $1,991,898,969,395$ & 2.60 & Sangat Kurang \\
\hline \multicolumn{3}{|c|}{ Rata-Rata } & 2.93 & Sangat Kurang \\
\hline
\end{tabular}

Berdasarkan tabel 5 dapat diketahui bahwa pada tahun 2015 pajak hotel memberikan kontribusi sebesar 2,97\% pada PAD Kota Tangerang. Sedangkan di tahun 2016 pajak hotel mengalami peningkatan dalam memberikan kontribusi terhadap PAD Kota Tangerang yaitu sebesar 3,21\%. Di tahun 2017 pajak hotel mengalami penurunan dalam memberikan kontribusi pada PAD Kota Tangerang dan lebih kecil dari tahun 2015 yaitu sebesar $2,60 \%$.

Realisasi pajak hotel dan realisasi PAD pada tahun 2015-2017 selalu mengalami peningkatan, namun pendapatan pajak hotel memberikan kontribusi yang sangat kurang terhadap pendapatan asli daerah Kota Tangerang dengan rata-rata sebesar 2,93\%.

Tabel 6 Kontribusi Pajak Restoran

\begin{tabular}{|c|c|c|c|c|}
\hline Tahun & $\begin{array}{c}\text { Realisasi Pajak } \\
\text { Restoran (Rp) }\end{array}$ & $\begin{array}{c}\text { Realisasi PAD } \\
(\mathbf{R p})\end{array}$ & $\begin{array}{c}\text { Kontribusi } \\
(\%)\end{array}$ & Kriteria \\
\hline 2015 & 211.725 .468 .574 & 1.471 .944 .383 .908 & 14,38 & Kurang Baik \\
\hline 2016 & 230.409 .614 .187 & 1.590 .080 .330 .000 & 14,49 & Kurang Baik \\
\hline 2017 & 247.765 .055 .842 & 1.991 .898 .969 .395 & 12,44 & Kurang Baik \\
\hline \multicolumn{3}{|c|}{ Rata-Rata } & 13,77 & Kurang Baik \\
\hline
\end{tabular}

Berdasarkan tabel di atas, realisasi pajak restoran dan realisasi PAD pada tahun 2015-2017 selalu mengalami peningkatan yang signifikan, namun pendapatan pajak restoran memberikan kontribusi yang kurang baik terhadap pendapatan asli daerah Kota Tangerang dengan rata-rata sebesar 13,77\%. 
Tabel 5 menunjukkan bahwa pada tahun 2015 pajak restoran memberikan kontribusi sebesar $14,38 \%$ pada PAD Kota Tangerang. Di tahun 2016 kontribusi pajak restoran terhadap PAD meningkat yaitu sebesar 14,49\%. Sedangkan di tahun 2017 kontribusi pajak restoran terhadap PAD
Kota Tangerang mengalami penurunan sebesar 12,44\%. Pajak restoran terhadap PAD Kota Tangerang mengalami penurunan sebesar $12,44 \%$. Pajak restoran selama tahun 2015-2017 masih kurang baik dalam berkontribusi pada PAD Kota Tangerang.

Tabel 7 Kontribusi Pajak Air Tanah

\begin{tabular}{|c|c|c|c|c|}
\hline Tahun & $\begin{array}{l}\text { Realisasi Pajak } \\
\text { Air Tanah (Rp) }\end{array}$ & $\begin{array}{l}\text { Realisasi PAD } \\
\text { (Rp) }\end{array}$ & $\begin{array}{c}\text { Efektivitas } \\
(\%)\end{array}$ & Kriteria \\
\hline 2015 & $5,941,131,044$ & $1,471,944,383,908$ & 0.40 & Sangat Kurang \\
\hline 2016 & $5,643,689,377$ & $1,590,080,330,000$ & 0.35 & Sangat Kurang \\
\hline 2017 & $5,569,725,821$ & $1,991,898,969,395$ & 0.28 & Sangat Kurang \\
\hline \multicolumn{3}{|c|}{ Rata-Rata } & 0.35 & Sangat Kurang \\
\hline
\end{tabular}

Berdasarkan tabel 7 dapat diketahui bahwa pada tahun 2015 pajak air tanah memberikan kontribusi sebesar $0,40 \%$ pada PAD Kota Tangerang. Sedangkan di tahun 2016 pajak air tanah mengalami penurunan dalam memberikan kontribusi terhadap PAD Kota Tangerang yaitu sebesar 0,35\%. Di tahun 2017 pajak air tanah mengalami penurunan kembali dalam memberikan kontribusi pada PAD Kota Tangerang dan lebih kecil dari tahun sebelumnya yaitu sebesar $0,28 \%$.

Realisasi pajak air tanah selalu menurun dari tahun 2015 sampai dengan tahun 2017, tetapi realisasi PAD pada tahun 2015-2017 selalu mengalami peningkatan yang signifikan, namun pendapatan pajak air tanah memberikan kontribusi yang sangat kurang terhadap pendapatan asli daerah Kota Tangerang dengan rata-rata sebesar $0,35 \%$.

\section{KESIMPULAN}

Tingkat efektivitas pajak hotel dan restoran, serta pajak air tanah selama tahun 2015-2017 tidak selalu menunjukkan peningkatan setiap tahunnya, tetapi tingkat efektivitas pajak hotel dan restoran, serta pajak air tanah Kota Tangerang masih dalam kriteria sangat efektif karena nilainya masih diatas $100 \%$. Rata-rata efektivitas pajak hotel Kota Tangerang pada tahun 2015-2017 adalah sebesar $117,37 \%$, sedangkan rata-rata efektivitas pajak restoran adalah sebesar $106,57 \%$, dan untuk rata-rata efektivitas pajak air tanah yaitu sebesar $107,34 \%$. Realisasi penerimaan pajak hotel dan restoran serta pajak air tanah selama tahun 2015-2017 sudah sangat baik karena melebihi dari target yang sudah ditetapkan. Peningkatan realisasi penerimaan pajak hotel dan restoran serta pajak air tanah harus dipertahankan dan ditingkatkan lagi. Kontribusi penerimaan pajak hotel dan restoran serta pajak air tanah pada Pendapatan Asli Daerah Kota Tangerang selama tahun 2015-2017 sangat kurang. Ratarata kontribusi pajak hotel Kota Tangerang pada tahun 2015-2017 adalah sebesar 2,93\% dengan kriteria sangat kurang, sedangkan ratarata kontribusi pajak restoran yaitu sebesar $13,77 \%$ dengan kriteria kurang baik, dan untuk rata-rata kontribusi pajak air tanah yaitu sebesar 
0,35\% dengan kriteria sangat kurang. Hal ini disebabkan dengan naiknya jumlah realisasi penerimaan pajak daerah lain yang cukup signifikan sehingga berpengaruh terhadap presentase kontribusi pajak hotel dan restoran serta pajak air tanah. Pendapatan Asli Daerah yang meningkat yaitu berasal dari Pajak Bumi dan Bangunan (PBB) serta Bea Perolehan Hak atas Tanah dan Bangunan (BPHTB).

\section{DAFTAR PUSTAKA}

Agoes, Sukrisno dan Estralita, Trisnawati. 2014. Akuntansi Perpajakan Edisi 3. Jakarta: Salemba Empat

B. Ilyas Wirawan dan Richard Burton. 2013. Hukum Pajak, Edisi 6. Jakarta : Salemba Empat

Badan Pengelola Keuangan Daerah (BPKD). Pemerintah Kota Tangerang, [Online], (http://e- ptpd.tangerangkota.go.id/mobile/, diakses 23 Oktober 2019).

Basuki, Yoyok Rahayu. 2017. A-Z Perpajakan : Mengenal Perpajakan. Magic Entertainment

Cermati.com. 2016. Pengertian Pajak, Fungsi dan Jenis-Jenisnya, [online], (https://www.cermati.com/artikel/pengertia n-pajak-fungsi-dan-jenis-jenisnya, diakses tanggal 06 Oktober 2019).

Dirvi Surya Abbas, Arry Eksandy. (2020). The Effect Of Effective Tax Rate, Tunneling Incentive, And Exchange Rate On Company Decisions To Transfer Pricing : Food And Consumption Sub-Sector Companies Listed On The Indonesia Evidence. Palarch's Journal Of Archaeology Of Egypt / Egyptology, 17(7), 14430-14442. Retrieved From Https://Archives.Palarch.N1/Index.Php/Jae/ Article/View/5486

Hidayat, Anwar. 2012. Penjelasan Desain Penelitian (Pengantar), [Online], (https://www.statistikian.com/2012/05/desa inMinahasa Selatan. Manado: Universitas Sam Ratulangi Manado

Mardiasmo. 2018. Perpajakan - Edisi Terbaru 2018. Yogyakarta: C.V Andi Offset

Priantara, Diaz. 2012. Perpajakan Indonesia. Edisi 2. Jakarta : Mitra Wacana Media.

Rahayu, Siti Kurnia. 2013. Perpajakan Indonesia : Konsep dan Aspek Formal. Yogyakarta : Graha Ilmu

Resmi, Siti. 2019. Perpajakan : Teori \& Kasus (Buku 1) (Edisi 11). Jakarta: Salemba
Empat

Ruangguru.Co.Id.2019. Pengertian Kontribusi Secara Umum Lengkap,

[Online],(https://www.ruangguru.co.id/pen gertian-kontribusi-secara-umum-lengkap/, diakses tanggal 23 Desember 2019)

Peraturan Daerah, Kota Tangerang, Nomor 11, Tahun 2010, tentang Pajak Hotel npenelitian-pengantar.html, diakses

tanggal 24 Oktober 2019) ～， tentang

Pajak Restoran

Kamus Besar Bahasa Indonesia. Pengertian Kontribusi [Online], https://kbbi.kemdikbud.go.id/, diakses tanggal 23 Desember 2019).

Kokorafa. 2012. Informasi Studi Lapangan, [Online], (http://kokorafa76.blogspot.com/2012/12/in formasi-studi-lapangan.html, diakses tanggal 23 Oktober 2019)

Lombogia, Agriani. 2016. Analisis Kotribusi Pajak Hotel Terhadap Pendapatan Asli Daerah PAD) Kabupaten , tentang Pajak Air Tanah

Peraturan Pemerintah Republik Indonesia Nomor 55, Tahun 2016, tentang Ketentuan Umum dan Tata Cara Pemungutan Pajak Daerah

Samudra, Azhari Aziz. 2015. Perpajakan di Indonesia : Keuangan, Pajak dan Retribusi Daerah. Jakarta : Rajawali Pers

Saputra, Wendy Dwi, Chairul Saleh dan Abdul Wachid. 2017. Kontribusi Pajak Pengelolaan Air Tanah terhadap Pendapatan Asli Daerah Kabupaten Malang pada unit Pelayanan terpadu Perijinan Kabupaten Malang. Malang: Universitas Brawijaya

Saputri, Shinta Rintis. 2017. Pemungutan Pajak Air Tanah dan Kontribusi terhadap Pendapatan Asli Daerah Kota Metro Lampung. Lampung: Universitas Lampung

Sedana, I Ketut Ari, Made Artana dan Kadek Rai Suwena. 2014. Efektivitas dan Kotribusi Pajak Hotel dan Pajak Restoran terhadap Pendapatan Asli Daerah (PAD) di Kabupaten Gianyar Tahun 2008-2012. Bali: Universitas Pendidikan Ganesha Singaraja

Situmorang, Christina Verawaty, Emma Rosinta Br. Simarmata dan Bilfrid Asyaria Simanullang. 2018. Analisis Efektivitas dan Kontribusi Pajak Hotel dan Restoran terhadap Pendapatan Asli Daerah Pada Kabupaten Deli Serdang. Medan: Universitas Methodist Indonesia

Sugiyono. 2017. Metode Penelitian Kualitatif, Kuantitatif, dan R\&D. Bandung : Alfabeta

Undang-Undang Nomor 16, Tahun 2009, tentang Ketentuan Umum dan Tata Cara Perpajakan 
Undang-Undang Nomor 28, Tahun 2009, tentang Pajak Daerah dan Retribusi Daerah

Undang-Undang Nomor 34, Tahun 2000, tentang Pajak dan Retribusi Daerah

Undang-Undang Nomor 33 tahun 2004, tentang Perimbangan Keuangan antara Pusat dan Pemerintah Daerah

Wulandari, Phaureula Artha dan Emy Iryanie. 2018. Pajak Daerah Dalam Pendapatan Asli Daerah. Sleman: Deepublish. 